
Canadian Journal of Educational Administration and Policy
Revue canadienne en administration et politique de l'éducation

CJEAP

\author{
Simpson, D. J. \& Sacken, D. M. (2021). Ethical Dilemmas in \\ Schools: Collaborative Inquiry, Decision-Making, and Action
}

\title{
Olivier Michaud
}

Numéro 197, 2021

URI : https://id.erudit.org/iderudit/1083336ar

DOI : https://doi.org/10.7202/1083336ar

Aller au sommaire du numéro

Éditeur(s)

Department of Educational Administration, University of Saskatchewan

ISSN

1207-7798 (numérique)

Découvrir la revue

\section{Citer ce compte rendu}

Michaud, O. (2021). Compte rendu de [Simpson, D. J. \& Sacken, D. M. (2021). Ethical Dilemmas in Schools: Collaborative Inquiry, Decision-Making, and Action]. Canadian Journal of Educational Administration and Policy / Revue canadienne en administration et politique de l'éducation, (197), 108-110. https://doi.org/10.7202/1083336ar 


\title{
Simpson, D. J. \& Sacken, D. M. (2021). Ethical Dilemmas in Schools: Collaborative Inquiry, Decision-Making, and Action. Cambridge University Press
}

\author{
Reviewed by: Olivier Michaud, Université du Québec à Rimouski
}

\section{Presentation of the Book}

In the first paragraph of Ethical Dilemmas in Schools: Collaborative Inquiry, Decision-Making, and Action, the authors, Douglas J. Simpson and Donal M. Sacken, make clear the goal of their book: "[it is] an introduction to democratic ethical inquiry and reflection and is designed for professors in educator preparation programs" (p. xiii). There are two central elements that inform their entire endeavor: the first is the philosophical foundation of the book and the second is its structure and organization. The philosophical foundation of the book is based on the thinking of John Dewey. Dewey's reflection on ethics, but also on other subjects, is the main perspective used throughout the book to explore the ethical dimensions of schooling and of education, although the authors will link them to others philosophical themes, such as, ethics of care and critical pedagogy. This evidences the authors' position regarding ethics in education, which is well summarized in the quote above as a "democratic ethical inquiry".

The structure of the book relates to its goal, namely, the book is to be used primarily in educator preparation programs. Ethical Dilemmas in Schools is not just a theoretical work, an introduction to ethics based on John Dewey's philosophy, but a pedagogical work. Although the pedagogical intent is certainly to transmit knowledge, it is more about creating a space for inquiry. The link between the philosophical foundation of the book and its structure is therefore obvious: to bring the readers to think by themselves and with each other on ethical matters. In addition of the presentation of ethical concepts and theories, different techniques are used to draw the readers into inquiry. The first one is the inclusion of various case studies throughout the book. These cases, which are presented as fictional but that might as well could have been inspired by actual cases, share a central character, a fictional principal called Maria De la Garza who worked in a K-12 high school, the Academy for Civic Responsibility. The connections between these cases and the key themes of each chapter are complex: they illustrate the theory creating a certain form of dialogue between ethical concepts and concrete situations. After the case is presented, the readers can follow the reflections of the principal regarding the issues. However, in accordance with the goal of the book, the authors do not present how the principal solves the problem, instead, the cases and reflections are presented as an invitation for personal reflection or collective dialogue, in other words, to engage in inquiry. Each chapter includes a discussion plans that can be used to elicit conversations among the students. Chapters also includes a "stop and think" moment that aims to bring the reader to reflect on certain questions. For the reader who wishes to further explore the topics, there is a list of annotated references included at the end of each chapter. In addition to this, the reader will find useful charts that summarize some of the ideas discussed in the chapter.

\section{Main Ideas}

The first chapter explains the nature of ethics, which can be summarized in the following quote: "ethics involves 'should questions' and wrestles with what an individual, a group, or a teacher, parent, or principal should not do in a particular problematic situation" (p. 9). Said differently, ethics are a concern for 
"those who examine problematic situations explore and interrogate claims of good and bad, right and wrong, virtue and vice, and prudence and imprudence." (p. 9) Two questions are introduced, which are at the heart of any reflection on ethics: "Who should decide what is right and wrong? And how should people decide what is right and wrong?" (p. 11). Dewey's answer to these two questions structure the theory that underlies the entire book. Regarding the first question (who should decide?), "everyone who has a stake in a problematic situation should have a voice in its resolution" (p. 11). Regarding the second question (how to decide?), the resolution should be done through inquiry. The process of inquiry is similar to the scientific method: identifying a problematic situation, finding the relevant data to the situation, establishing hypothesis, testing and revising hypothesis, enunciating conclusion. In the Deweyan perspective, this inquiry process never ends and should always be done anew. The never-ending character of the process of inquiry is true of any field, as new information should lead us to revise our previous beliefs. However, the necessity of this inquiry process is a bit different regarding ethics, as ethical issues are necessarily about specific and unique situations involving particular individuals.

The second chapter brings up the topic of empathy. It appears that Dewey mainly used the term of 'sympathy', which was the term available to him at his time. He, according to the authors, used it in the sense we use 'empathy' today, as sympathy as now a different meaning. Empathy should be included in the inquiry process, which means firstly to care about what others feel and to try to understand how they see a situation. Ethical judgments are better if we are able to decenter from our perspective to take into consideration the perspective of others. Empathy, however, should be linked to other elements involved in ethical judgment, such as reflection on ethical principles, consciousness of one's biases, or the gathering of relevant facts to a problematic situation.

Ethical principles are discussed in the third chapter. Principles are different than rules: "a rule is a practical term that usually conveys the idea of adhering to an inflexible prescription, but he [Dewey] thought that principle connotes a flexible intellectual instrument that helps one gain insight into ethical situations and its resolution.” (p. 52) Therefore, ethical principles should not be seen as giving us laws that we should obey in every ethical problematic situation. They are, however, a piece of information that should be taken into account, but we should examine how they apply to different contexts. Furthermore, they should be constructed or, better, co-constructed through inquiry.

The chapter 4 studied what having regard for others implies. The first point that is made in the chapter is that having regard to others is not antithetical of having regard for oneself. This means that being conscious of the ethical dimension of our life is more likely to help us to have a fulfilling, meaningful and happy life. The chapter then opens the meaning of who is the other? It can mean to be conscious of the different persons involved in a situation: students, colleagues, administrators, neighbors (close and distant), family, etc. It also means to be able to grasp people's desires, culture, aptitudes, purposes, challenges, values, etc. At this point the authors add another complexity of what regard of other implies, namely, to be conscious of one's biases, to be able to consider the consequences of a decision, and to ponder on the common good. The chapter concludes with the reminder that "regard for others" should also lead to action. Personally, this has been one of my main takeaways of this book, as it opens the reader to various dimensions of what should be considered when facing an ethical dilemma. It broadens our perspective regarding ethical situations.

Chapter 5 pursues the clarification of what is a problematic situation? It delves further in what must be taken into account in judging a particular situation. Chapter 6 moves toward the ethical qualities and characteristics that educators should possess or look to acquire, as they can never be fully acquired. The authors underline four qualities that good educators should have. First, they should have wisdom: "Broadly, it is the utilization of knowledge or understanding that informs one's pursuit of 'the better living of life' (MW 8, 163)." (p. 141) Second, they should be trustworthy, which means to act in the best interest of others. Third, they should be thoughtful, particularly in making evaluative judgment, considering how they affect the persons that we are judging. Fourth, they should be conscientious and deliberative, "including seeking information that clarifies issues and identifies the consequences of proposed choices" (p. 159). It is important to note that these four qualities not only characterize the ethical educator, but also any concerned adults, and students, therefore, becoming the foundational principles of ethical thinking in schools. Further, education is not only about transmitting knowledge, it is also about creating an environment that will help to educate ethical human beings. Such links between ethics and education in its large sense are well drawn in all the chapters. 
The last chapter moves to the kind of community that is more conducive to resolve ethical problems and to live an ethical life as presented in the book. It is not a surprise at this point that such community should be democratic and that schools should be seen as democratic communities. Hence, inquiry, as presented through the entire book, requires a community that, obviously, favors inquiry, that values individuals who are able to think by themselves, to dialogue with others, and to act collaboratively. As mentioned, ethics is not only a subject that concerns teachers or administrators, but also students, as they are acculturated in the democratic way life. It is worth noting that for Dewey democratic education is also the most effective form of education, as it is more likely to foster the "growth" of the students, their ability to interact with their various environments, as well as their ability to continually keep learning. It is not to say that the method proposed in the book is easy to apply or that it will resolve all the conflicts that we face, but that this method should guide us in our personal life and in building the community we aim to live in. A project that always has to be done anew.

\section{The Use of this Book}

This book is an excellent introduction to Dewey's theory of ethics, but also to his philosophy of education. It is a thorough presentation of his ideas and it is based on an extensive research. Connections of his thinking to current issues are also made, regarding empathy, caring. and social justice. Particularly, concerning the last concept, different forms of injustices related to race, gender and social class are discussed throughout the book.

Regarding the use of this book in teacher educational training, there are two points that must be considered. As mentioned above, the book is mainly centered on Dewey's philosophy. Dewey is a central figure in the history of philosophy of education and, without any doubt, remains relevant regarding current discussions in ethics. However, teachers giving an ethics class have to consider if they wish to situate themselves in that perspective. Second, I will also note that the main character in the case studies of the book is a principal. If students in school administration may relate easily to her, it may be less evident to

students in teacher education programs. These two concerns could, however, be remediated through the use of secondary theoretical texts and case studies.

\section{References}

Simpson, D. J. et Sacken, D. M. (2021). Ethical Dilemmas in Schools: Collaborative Inquiry, Decision-Making, and Action. Cambridge Univrsity Press. 